\title{
ENVIRONMENTAL FRAGILITY OF THE IRAÍ RIVER BASIN - WATER SUPPLY SOURCE FOR CURITIBA, PARANÁ
}

\author{
Amanda Köche Marcon ${ }^{1 *}$, Christel Lingnau², Franklin Galvão \\ ${ }_{1}$ Universidade Federal do Paraná, Programa de Pós-Graduação em Ciências Florestais, Curitiba, Paraná, Brazil - amandakoche@gmail.com \\ ${ }^{2}$ Universidade Federal do Paraná, Departamento de Ciências Florestais, Curitiba, Paraná, Brazil - lingnau@ ufpr.br \\ 3Universidade Federal do Paraná, Departamento de Ciências Florestais, Curitiba, Paraná, Brazil - fgalvao@ufpr.br
}

Received for publication: 10/12/2019 - Accepted for publication: 16/06/2021

\begin{abstract}
Resumo
Fragilidade ambiental da bacia do rio Iraí - manancial de abastecimento de Curitiba, Paraná. Este estudo teve por objetivo comparar dois métodos de determinação da fragilidade ambiental de um importante manancial da região de Curitiba, Paraná, a bacia do rio Iraí. A determinação da fragilidade ambiental foi realizada a partir da integração das características geológicas, pedológicas, geomorfológicas e uso do solo, utilizando os métodos de fragilidade emergente e Vulnerabilidade Natural à Perda de Solo. A bacia do rio Iraí foi majoritariamente classificada como de fragilidade ambiental fraca a média, pelos dois métodos. Os métodos apresentaram classificações de fragilidade iguais em $74 \%$ da área da bacia. As maiores fragilidades estão onde a sedimentação é recente, solos com alta instabilidade, declividades superiores a $12 \%$ e áreas com uso do solo de baixo potencial protetor. O método de determinação da fragilidade emergente realçou o efeito do uso do solo, acentuando a fragilidade de classes mais vulneráveis, enquanto o método de determinação da Vulnerabilidade Natural à Perda do Solo atenuou o efeito do uso do solo, suavizando a vulnerabilidade. Os mapas de fragilidade indicaram que resultados diferentes podem ser obtidos, sobretudo no limiar entre classes de fragilidade e para polígonos onde a classe de uso do solo torna o ambienta mais vulnerável. Assim, a seleção do método para determinar a fragilidade ambiental depende da relevância necessária para o uso e ocupação do solo, sendo o método da fragilidade emergente adequado para evidenciar a fragilidade em áreas majoritariamente ocupadas por classes de uso do solo de alta vulnerabilidade.

Palavras-chave: vulnerabilidade ambiental, sistema de informação geográfica (SIG), suscetibilidade à erosão, monitoramento ambiental
\end{abstract}

\begin{abstract}
This research aimed to compare two methods of determining the environmental fragility of a vital source in the region of Curitiba, Paraná, the Iraí river basin. The determination of the environmental fragility was carried out based on the integration of geological, pedological, geomorphological characteristics and land use, using the emergent fragility and Natural Vulnerability to Soil Loss methods. Most of the Iraí River basin was classified as weak to intermediate environmental fragility by both methods. The methods showed equal fragility ratings in $74 \%$ of the basin area. The greatest fragilities were found in areas with recent sedimentation, soils with high instability, slopes higher than $12 \%$ and land use areas with low protective potential. The emergent fragility method highlighted the effect of land use, accentuating the fragility of the most vulnerable classes. In contrast, the Natural Vulnerability to Soil Loss method attenuated this land-use effect, softening the vulnerability. The fragility maps indicated that different results might be obtained, especially on the threshold between fragility classes and polygons where land-use makes the environment more vulnerable. Thus, the method selection for determining environmental fragility depends on the relevance necessary for land-use. The emergent fragility method is advantageous for showing the fragility in areas mainly occupied by classes of land use of high vulnerability.
\end{abstract}

Keywords: environmental vulnerability, geographic information system (GIS), erosion susceptibility, environmental monitoring

\section{INTRODUCTION}

The Iraí river basin is the primary water supply source in the Alto Iguaçu region, being essential in supplying drinking water for the population in Curitiba's Metropolitan Region. Overall, water catchment areas at the Alto Iguaçu river basin are contaminated, mainly due to the irregular real estate occupation of floodplains and watershed spring areas (KNAPIK et al., 2011). Added to disorderly agricultural development, the occupation of spring areas can lead to drinkable water shortage due to excessive irrigation or the contamination of watershed by fertilisers, pesticides, and urban residues (AQUINO et al., 2017). Therefore, there has been an increasing interest in monitoring the impact of human activities in spring areas that supply drinking water for the public (FARLIN $e t$ $a l ., 2019)$, especially due to these systems' fragility depending on the type and intensity of human activity they are subjected to (SPÖRL; ROSS, 2004).

With the increasing water resources demand added to the progressive degradation of the planet's reserves, it becomes even more evident the importance of carrying for the preservation of watersheds, especially the 
development of tools to assess the impact of human activities on them (GONÇALVES et al., 2011). In order to analyse a natural landscape unit, it is necessary to understand its origin, physical constitution, evolutionary stage, and the type of vegetation that covers it. This data is obtained by investigating the landscape's geology, geomorphology, pedology, and phytogeography. Integrating these variables is an efficient way of evaluating the behaviour of each unit against its characteristics (RASHID et al., 2012).

The environmental fragility empirical analysis' principle proposed by Ross (1994) considers that environments are stable when in dynamic balance: areas in which morphogenetic processes dominate are considered unstable, while areas in which pedogenesis dominates are considered stable. Considering that human activities alter the functionalities of natural environments, studies on environmental fragility can define guidelines and actions to be implemented in the physical-territorial area. These studies can also serve as a base for zoning and area management, aiding in the adoption of conservation practices (SPÖRL; ROSS, 2004; GOMES, 2013).

The present study aims to empirically analyse the environmental fragility of the Iraí river basin by comparing two methods, using geological, pedological, geomorphological, and land use and occupation data. The environmental fragility evaluation proposed by Ross (1994) identifies the emerging fragility by attributing greater relevance to land use and occupation, in contrast with the Natural Vulnerability of Soil Loss (NVSL) method proposed by Crepani et al. (1996). This study's guiding hypothesis is that the Iraí river basin presents high environmental fragility. Therefore, conservation actions must be put into practice to maintain and preserve the freshwater supply for Curitiba and the Metropolitan Region.

\section{MATERIAL AND METHODS}

Originated at the western edge of the Serra do Mar, State of Paraná, the Iraí river is the primary water catchment source for water abstraction at the Alto Iguaçu basin. With an area of $112 \mathrm{~km}^{2}$, the Iraí river basin extends over five municipalities (Figure 1). In the eastern region of Curitiba, it meets the Atuba river becoming the Iguaçu river. The region's climate is Cfb, following the Köppen classification, being characterised as moist temperate, without a dry season, and with cool summers (ALVARES et al., 2013). The vegetation is classified as Araucaria Forest (SOUZA, 2020).

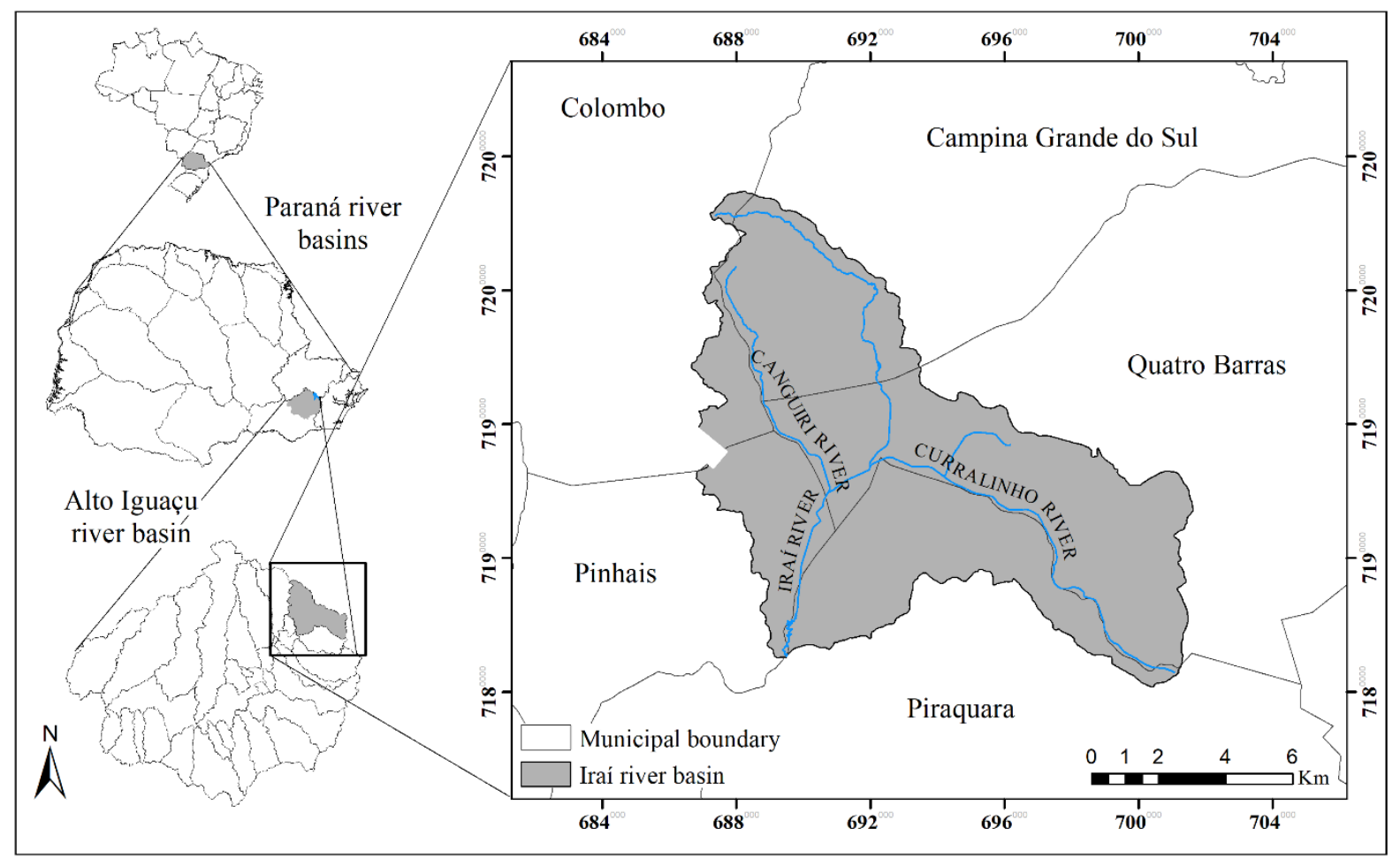

Figure 1. Location of the Iraí river basin, State of Parana, Brazil.

Figura 1. Localização da bacia do rio Iraí, PR, Brasil.

In order to evaluate the fragility of the watershed environment at the Iraí river basin, we characterized the biophysical data: (1) rocky substrate; (2) geomorphology; (3) soil classes; and (4) land use and occupation. The cartographic base and the biophysical data were provided by the Sistema Estadual de Informações de Recursos 
Hídricos (SEIRHI - State Water Resources Information System) in vector format in 1:20.000 (rocky substrate and land use and occupation) and 1:10.000 (hydrography and altimetry) scales (AGUASPARANA, 2015). Soil data was provided by the Empresa Brasileira de Pesquisa Agropecuária (EMBRAPA - Brazilian Agricultural Research Company) in 1:250.000 scale. The soil, declivity and land use and occupation vulnerability values were obtained following Ross (1994), who classifies the vulnerability into five hierarchical classes: (1) very low; (2) low; (3) intermediate; (4) high; and (5) very high. These classes are applied to each biophysical data type contributing to environmental stability/instability (Table 1). For the rocky substrate, we used values following Crepani et al. (1996).

Table 1. Vulnerability values of the biophysics data from the Iraí river basin. Adapted from Crepani et al. (1996) and Ross (1994).

Tabela 1. Valores de vulnerabilidade dos dados biofísicos da bacia do rio Iraí. Adaptado de Crepani et al. (1996) e Ross (1994).

\begin{tabular}{lccclccc}
\hline Attribute & $\mathbf{V}$ & $\begin{array}{c}\text { Area } \\
\left.\mathbf{( k m}^{2}\right)\end{array}$ & $\begin{array}{c}\text { Area } \\
(\boldsymbol{\%})\end{array}$ & Attribute & V & $\begin{array}{c}\text { Area } \\
\left(\mathbf{k m}^{\mathbf{2}}\right)\end{array}$ & $\begin{array}{c}\text { Area } \\
(\boldsymbol{\%})\end{array}$ \\
\hline Rocky substrate & & & & Geomorphology (declivity) & & & \\
Gneissic-Migmatitic complex & 2 & 21.46 & 19.2 & $12-20 \%$ & 3 & 9.66 & 8.6 \\
Granitic-Gneissic complex & 2 & 3.98 & 3.6 & $20-30 \%$ & 4 & 4.44 & 4.0 \\
Guabirotuba formation & 4 & 54.63 & 48.9 & $>30 \%$ & 5 & 1.54 & 1.4 \\
Alluvial terraces & 5 & 6.76 & 6.0 & Land use and occupation & & & \\
Current alluviums & 5 & 24.95 & 22.3 & Natural tree cover & 1 & 29.25 & 26.2 \\
Soils & & & & Forest stand & 2 & 7.53 & 6.7 \\
Red-Yellow Latosol & 1 & 50.39 & 45.1 & Natural shrub layer & 2 & 4.01 & 3.6 \\
Haplic Cambisol & 4 & 18.44 & 16.5 & Urban area & 3 & 8.78 & 7.9 \\
Red-Yellow Ultisol & 4 & 4.48 & 4.0 & Grasslands & 3 & 43.75 & 39.1 \\
Rocky Outcrops & 5 & 11.79 & 10.5 & Permanent agriculture & 3 & 0.07 & 0.1 \\
Melanic Gleysol & 5 & 2.14 & 1.9 & Water & 4 & 5.75 & 5.1 \\
Haplic Organosol & 5 & 24.54 & 22.0 & Temporary agriculture & 4 & 10.42 & 9.3 \\
Geomorphology (declivity) & & & & Mining & 5 & 0.88 & 0.8 \\
< 6\% & 1 & 73.62 & 65.9 & Exposed soil & 5 & 0.60 & 0.5 \\
6-12\% & 2 & 22.52 & 20.2 & Unclassified & - & 0.74 & 0.7 \\
\hline Where V Vulnerability value & & & & & & &
\end{tabular}

According to Ross (1994), the environmental fragility's empirical analysis can be done based on: (1) Potential Fragility (PF), which only considers natural characteristics (e.g., relief, soil, and climate); and (2) Emergent Fragility (EF), which takes into consideration natural characteristics together with anthropisation due to the inclusion of land use and occupation. The climate was excluded from our analysis since it is constant throughout the Iraí river basin, with the rain being evenly distributed year-round (ALVARES et al., 2013). The PF was calculated based on the vulnerability of each layer: (1) geological formation (Figure 2A), soil class (Figure 2B), and declivity (Figure 2C) (Eq. 1, based on Ross, 1994). Despite Ross (1994) not including the geological formation's vulnerability as a determinant factor in assessing environmental fragility, the author mentions it can also be included in the proposed model. To evaluate the EF (Eq. 2, based on Ross, 1994), we combined the PF data with the land use and occupation (LU) (Figure 2D).

$$
\begin{aligned}
& \mathrm{PF}=\frac{(\mathrm{RS}+\mathrm{GM}+\mathrm{SL})}{3} \\
& \mathrm{EF}=(\mathrm{PF}+\mathrm{LU})
\end{aligned}
$$

Where: $\mathrm{PF}=$ Potential Fragility; $\mathrm{EF}=$ Emergent Fragility; RS = Rocky substrate vulnerability; GM = Geomorphology (declivity) vulnerability; SL = Soil vulnerability; and LU = Land use and occupation vulnerability.

Despite being possible to define environmental vulnerability as the degree of susceptibility of a natural system to external interactions (AQUINO et al., 2017), Crepani et al. (1996) adopt the term Natural Vulnerability of Soil Loss (NVSL). The NVSL is determined by the arithmetic average of the RS, GM, SL, and LU vulnerabilities (Eq. $3)$. The climate was not taken into account when calculating the Iraí river basin's NVSL.

$$
N V S L=\frac{(R S+G M+S L+L U)}{4}
$$


Where: NVSL = Natural Vulnerability of Soil Loss; RS = Rocky substrate vulnerability; GM = Geomorphology (declivity) vulnerability; SL = Soil vulnerability; and LU = Land use and occupation vulnerability.

The RS vulnerability was obtained using the soil denudation (weathering and erosion) vulnerability index, following Crepani et al. (1996) and based on the geological formations present at the Iraí river basin (MINEROPAR, 2005). Alternatively, the GM vulnerability was defined by the declivity classes, where we use the critical geotechnics values indicative of the erosive processes' vigour and the risk of landslides and flooding (ROSS, 1994). The declivity values were obtained using the digital terrain model (DTM). Regarding land use and occupation in urban areas, we adopted an intermediate soil protection value (3) since it is dependent on characters such as soil waterproofing, green areas, and infrastructure (ROSS, 1994).

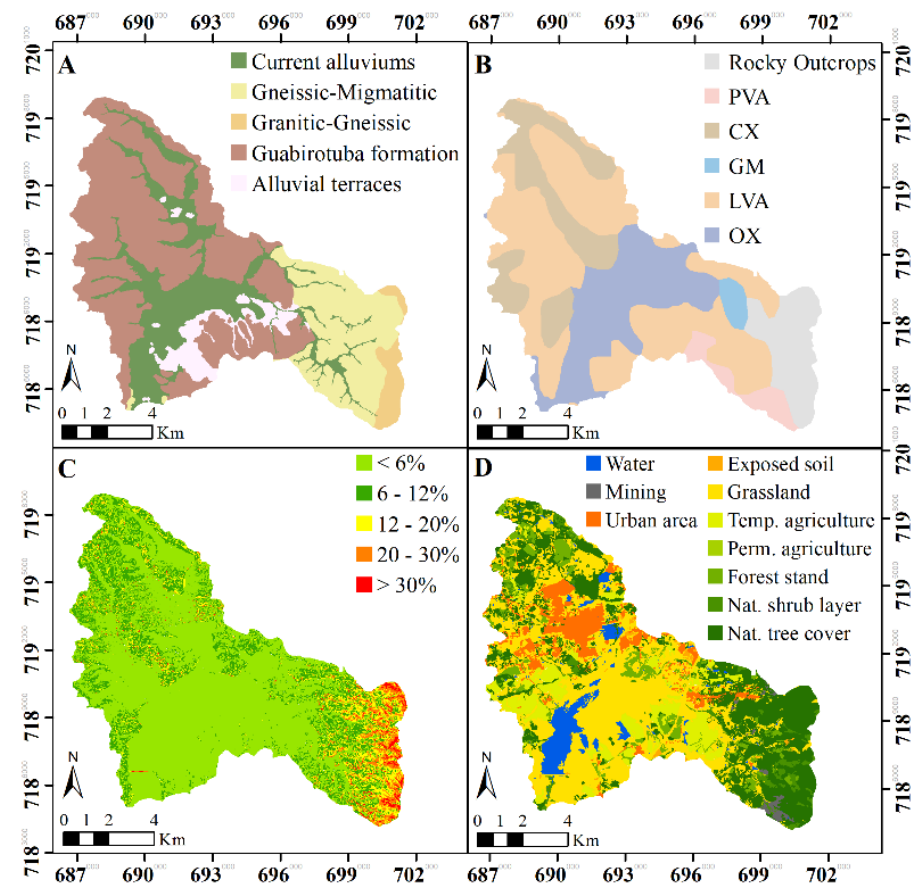

Figure 2. Geological classes (A), Soil classes (B), Declivity classes (C) and Land use and occupation (D) at the Iraí river basin, State of Parana, Brazil. Where: PVA = Red-Yellow Argisols; CX = Haplic Cambisols; $\mathrm{GM}=$ Melanic Gleysols; LVA = Red-Yellow Latosols; OX = Haplic Organosols.

Figura 2. Substrato rochoso (A), Classes de solo (B), Declividade (C) e Uso e ocupação do solo (D) da bacia do rio Iraí, PR, Brasil. Onde: PVA = Argissolo Vermelho-Amarelo; CX = Cambissolo Háplico; GM = Gleissolo Melânico; LVA = Latossolo Vermelho-Amarelo; OX = Organossolo Háplico.

In order to facilitate comparing the results for both employed methods, EF and NVSL, we accepted five hierarchical environmental fragility classes: (1) very low; (2) low; (3) intermediate; (4) high; and (5) very high. For results analysis and presentation, we recognised the fragility class intervals ( $F)$ : very low to low $(F \geq 2)$; low to intermediate $(2>\mathrm{F} \leq 3)$; intermediate to high $(3>\mathrm{F} \leq 4)$; and high to very high $(\mathrm{F}>4)$.

The intermediate vulnerability maps were prepared for each biophysical variable and land use and occupation. Therefore, it was possible to obtain the EF and NVSL maps for each of them. Considering that the EF and NVSL weigh land use and occupation differently, they were compared using the results obtained for each environmental fragility class. According to Ross (1994), the units become unstable whenever anthropic interventions intensely modify natural environments through deforestation and other economic activities. Consequently, the author considers that land use and occupation must be considered of greater relevance when assessing an area's environmental fragility. To indicate the methodological differences between EF and NVSL, we calculated the Difference (Dif) (Eq. 4), recovered the areas where the classification differed between both methods, and assessed their land use and occupation category. Spatial analyses were performed using the ArcGis 10.3 (ESRI) software, and the remaining analyses were performed using a virtual spreadsheet.

$$
\text { Dif }=\mathrm{EF}-\mathrm{NVSL}
$$

Where: Dif = Difference between EF and NVSL; EF = Emergent Fragility; NVSL = Natural Vulnerability of Soil Loss. 


\section{RESULTS}

The occurrence of RS typologies as presenting high to very high vulnerability is expressive, mainly when associated with alluvial sediment types and alluvial terraces (Figure 3A). The RS referring to the intermediate to high vulnerability class corresponds to the Guabirotuba formation (Figure 3A) and covers $48.87 \%$ of the Iraí river basin (Table 1). The RS classified as presenting lower vulnerability correspond to the Gneissic-Migmatitic and the Granitic-Gneissic complexes Figure 3A).

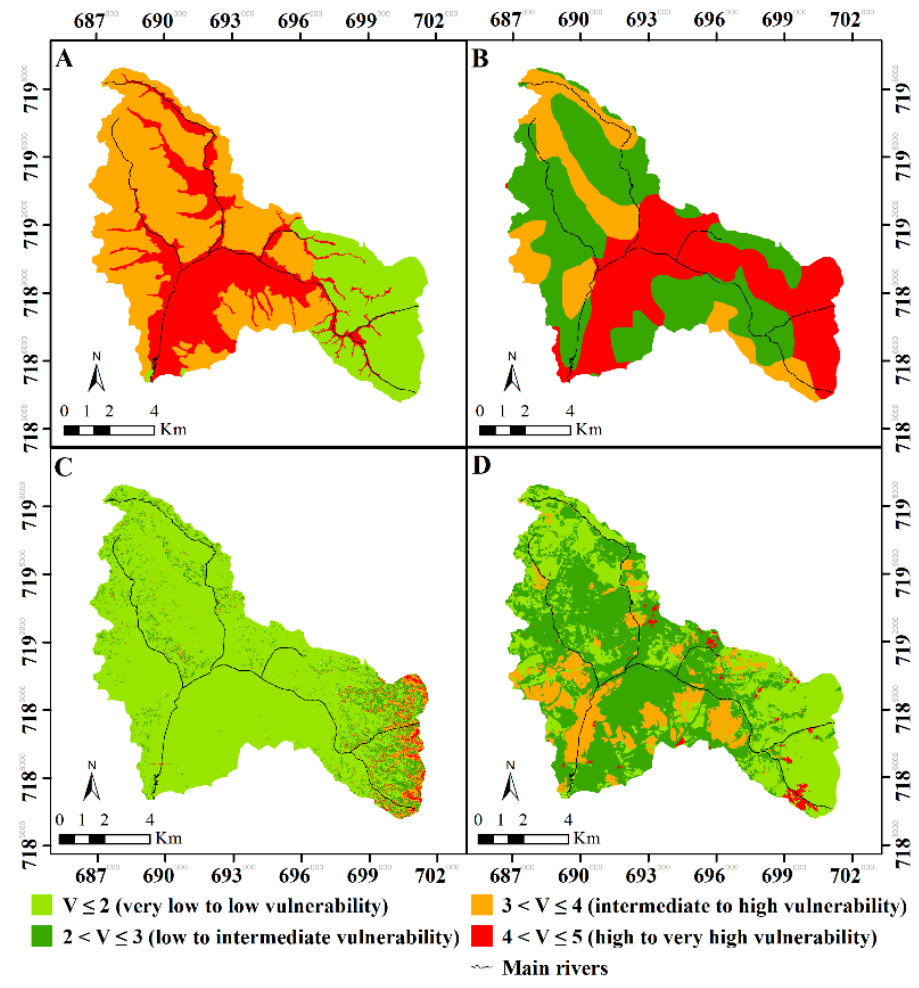

Figure 3. Vulnerability classes of the biophysical data for the Iraí river basin, State of Parana, Brazil: Geological classes (A), Soil classes (B), Declivity classes (C), and Land use and occupation (D).

Figura 3. Vulnerabilidades dos dados biofísicos da bacia do rio Iraí, PR, Brasil: Substrato rochoso (A), Classes de solo (B), Declividade (C) e Uso e ocupação do solo (D).

Soil vulnerability reflects greater instability in Organosols, Gleissols, and rocky outcrops (Figure 3B). Regions with intermediate to high soil vulnerability are the ones with Red-Yellow Argisols and Haplic Cambisols (Figure 3B). Regarding geomorphology, the declivities in the basin are mostly up to $12 \%$ and present very low to low vulnerability (Table 1; Figure 3C). Greater declivities are only found on the eastern portion of the basin.

Regarding land use and occupation, there is a predominance of the very low to low and low to intermediate vulnerability classes. This is caused by the wide extension of natural forests and grasslands, which respectively correspond to $26.34 \%$ and $39.40 \%$ of the basin's area (Figure 3D). However, it is important to highlight that the database provided by the SEIRHI does not provide further information on the grassland areas, making it impossible to differentiate natural grasslands - which would be fulfilling their environmental function - from artificial ones - caused by fires, deforestation, agriculture and/or livestock - . High vulnerabilities are observed in areas with exposed soil and mining activities, which correspond to $1.34 \%$ of the basin area (Table 1; Figure 3D).

The Iraí river basin's PF, obtained by integrating the RS, GM and declivity attributes but discounting LU (Figure 4A), demonstrated that $23.08 \%$ of the basin's area is assessed as having very low to low vulnerability levels. This result is associated with the occurrence of Latosols and declivities up to $12 \%$, being considered as a fairly dynamic topography (IBGE, 2007).

The EF (Figure 4B) results from the intersection between the PF (Figure 4A) and the vulnerability of the land use and occupation class (Figure 3D). Overall, our results indicate that the pressure caused by land use and occupation in the eastern and western regions of the basin reduce the impact. They also improve the EF values, which shifted from "intermediate to high" to "low to intermediate" due to its natural tree and bush cover. Mos t of the basin's area was assessed as presenting "low to intermediate" fragility (47.7\%). Generally, in the peripheral parts of the basin, we observe an increase in the "low to intermediate" fragility class at the expense of decreasing 
the "very low to low" class. Furthermore, there is also an increase of the "high to very high" fragility class, which now occupy $0.39 \%$ of the area, strongly associated with mining activities.

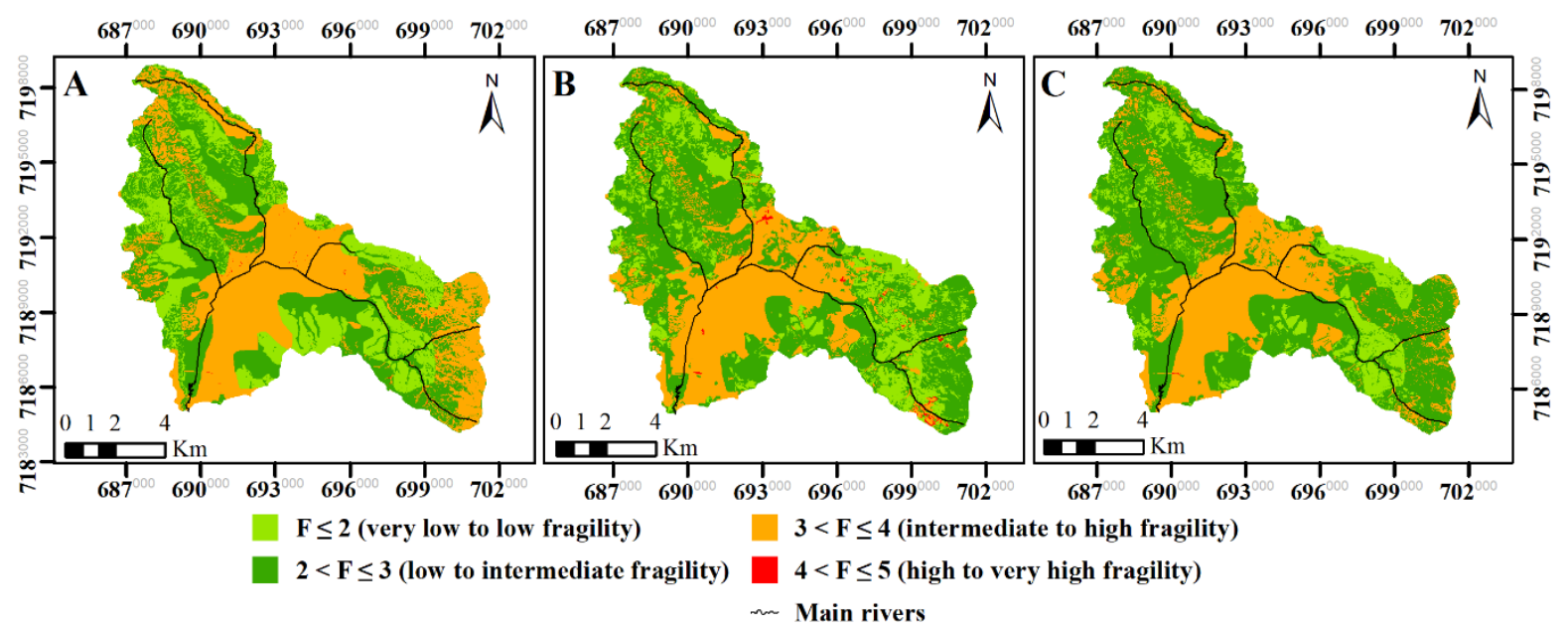

Figure 4. Potential fragility (A), Emergent fragility (B), and Natural Vulnerability of Soil Loss (C) for the Iraí river basin, State of Parana, Brazil.

Figura 4. Fragilidade potencial (A), Fragilidade emergente (B) e Vulnerabilidade Natural a Perda do Solo (C) da bacia do rio Iraí, PR, Brasil.

The results of the NVSL equation (Figure 4C) indicate that the "low to intermediate" fragility class was the dominant one in the basin (55.4\%). Overall, there was a decrease in areas matching the "very low to low", together with the increase of areas assessed under the low to intermediate class, compared with the EF values (Table 2).

Table 2. Area within each class of Emergent Fragility (EF) and Natural Vulnerability of Soil Loss (NVSL) for Iraí river basin, State of Parana, Brazil.

Tabela 2. Área incorporada em cada classe de fragilidade emergente (EF) e de Vulnerabilidade Natural de Perda de Solo (NVSL) da bacia do rio Iraí, PR, Brasil.

\begin{tabular}{|c|c|c|c|c|c|c|}
\hline & & \multicolumn{4}{|c|}{ Emergent Fragility $(\mathrm{EF})-\mathbf{k m}^{2}(\%)$} & \multirow{2}{*}{$\begin{array}{c}\text { Total } \\
\mathbf{k m}^{2}(\%)\end{array}$} \\
\hline & & $\begin{array}{c}\begin{array}{c}\text { Very low to } \\
\text { low }\end{array} \\
\end{array}$ & $\begin{array}{c}\text { Low to } \\
\text { intermediate }\end{array}$ & $\begin{array}{c}\text { Intermediate } \\
\text { to high }\end{array}$ & $\begin{array}{c}\text { High to very } \\
\text { high }\end{array}$ & \\
\hline \multirow{5}{*}{ 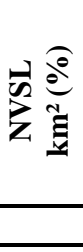 } & Very low to low & $14.15(12.7)$ & $1.87(1.7)$ & & & $16.03(14.34)$ \\
\hline & Low to intermediate & $7.6(6.8)$ & 48.89 (43.7) & $5.4(4.83)$ & & $61.89(55.37)$ \\
\hline & Intermediate to high & & $2.55(2.3)$ & $30.86(27.6)$ & $0.42(0.37)$ & $33.83(30.26)$ \\
\hline & High to very high & & & $0.01(0.01)$ & $0.02(0.02)$ & $0.03(0.03)$ \\
\hline & Total $-\mathbf{k m}^{2}(\%)$ & $21.76(19.46)$ & $53.31(47.69)$ & $36.27(32.45)$ & $0.44(0.39)$ & $111.78(100)$ \\
\hline \multicolumn{6}{|c|}{ Areas with a change in the vulnerability class $-\mathbf{k m}^{2}(\%)$} & $17.86(16)$ \\
\hline
\end{tabular}

The overlap of the EF and NVSL maps allowed us to identify that in $16 \%$ of the Iraí river basin area, both methods provided distinct results for both the increase and the decrease of the fragility levels (Figure 5; Table 2). For the "very low to low" fragility class, the results for both methods were congruent in $12.7 \%$ of the study area. Alternatively, in the NVSL analysis, $6.8 \%$ of the study was classified as "low to intermediate" fragility. This class was the most affected by the method used to assess the area's fragility indexes, despite some discrepancies having been observed for all fragility classes.

In cases where LU has a lower vulnerability, such as natural tree cover, forest stand, and natural shrub layer, the NVSL value was lower than EF (negative differences, Figure 6). The method used by Crepani et al. (1996) attenuated the effect of the LU categories, decreasing the fragility value. Alternatively, the EF was greater than the NVSL (positive differences, Figure 6) when LU was more vulnerable, such as water, temporary agriculture, mining, and exposed soil. The EF method highlights the effects of LU, increasing the fragility values. Exceptions were observed in extreme cases where the biophysical data, such as geology, soil and declivity, present "high to very high" vulnerability, even under intermediate LU vulnerability (urban areas and grasslands). 


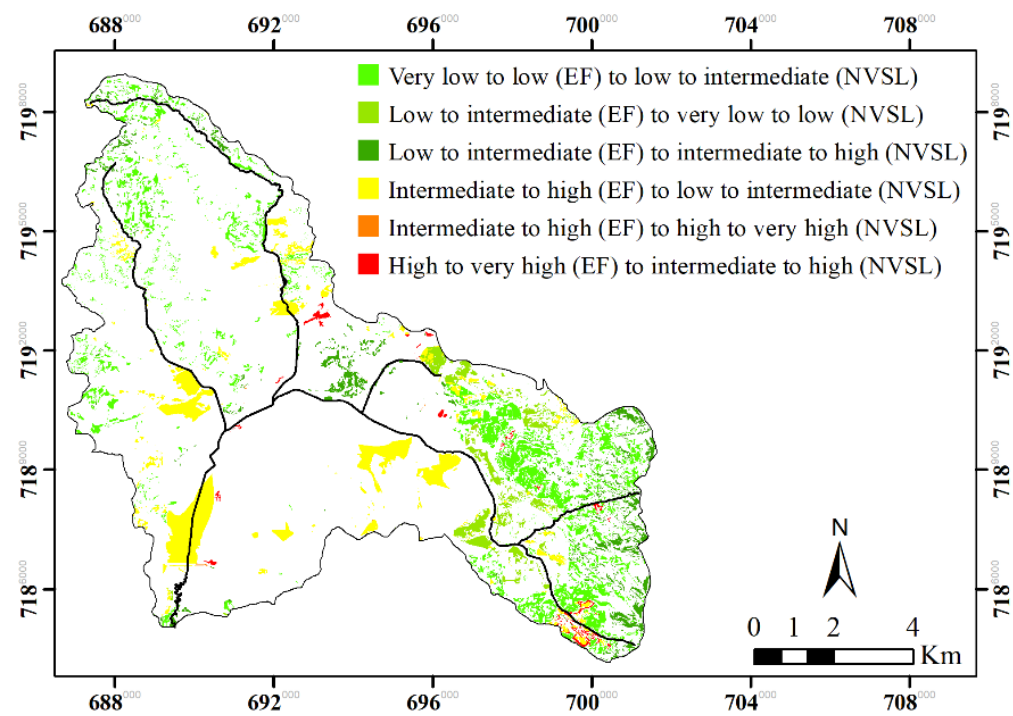

Figure 5. Intersection results between the Emergent Fragility (EF) method (Ross, 1994) and the Natural Vulnerability of Soil Loss (NVSL) method (Crepani et al., 1996) in the water source environment of the Iraí river basin, PR state. Blank areas indicate no change and coloured polygons indicate changes in the fragility class.

Figura 5. Resultados da intersecção entre a Fragilidade Emergente (EF) (Ross, 1994) em relação á Vulnerabilidade Natural a Perda do Solo (NVSL) (Crepani et al., 1996) no ambiente manancial da bacia do rio Iraí, PR. Áreas em branco indicam que não houve alteração e polígonos coloridos indicam alteração da classe de fragilidade, conforme legenda.

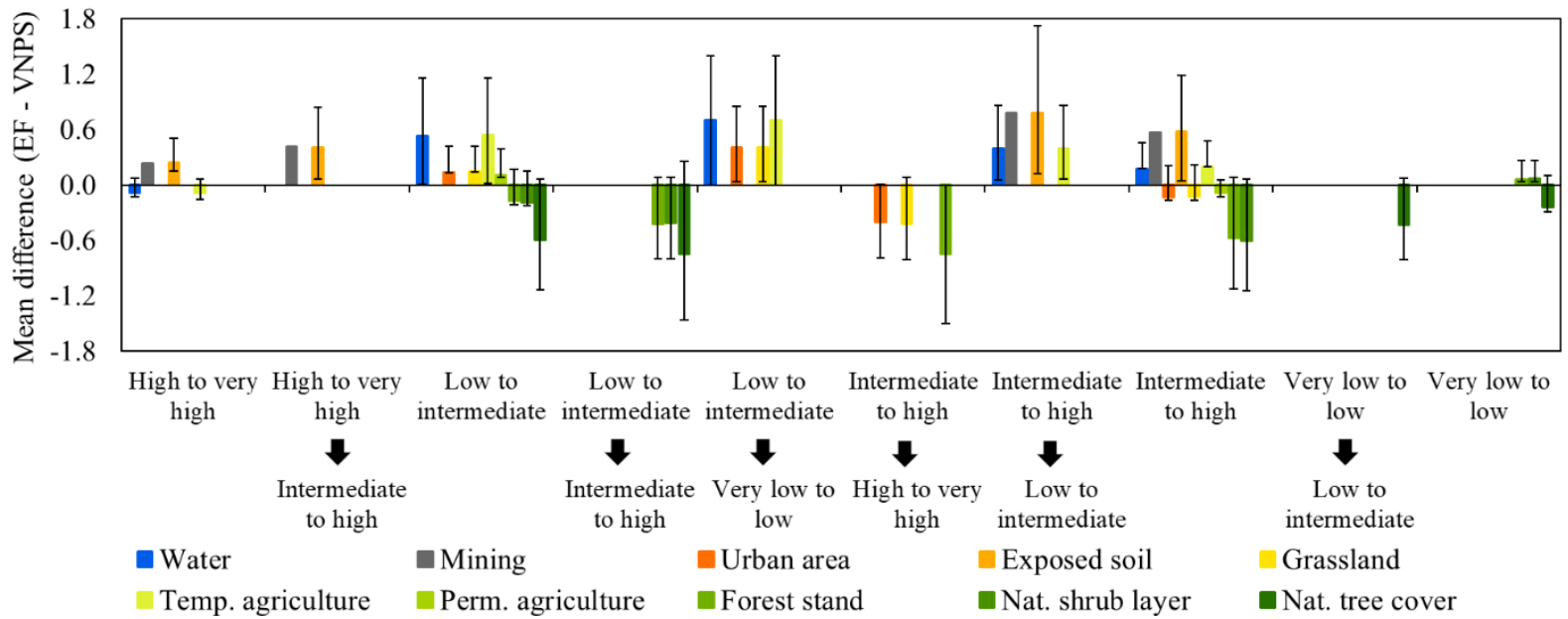

Figure 6. Mean difference between the environmental fragility methods (EF - NVSL) for the Land use and occupation (LU) classes. Bars represent the minimum and maximum mean values, and the black arrows represent class changes.

Figura 6. Resultados da diferença média entre os métodos de fragilidade do ambiente (FE - VNPS) para as classes de uso e ocupação do solo. Barras representam valores mínimos e máximos médios, e as setas pretas representam alteração de classe.

\section{DISCUSSION}

In general, both methods indicate that the Iraí river basin presents low to intermediate fragility. The greatest environmental fragility values were observed at the basin's central area, where the Iraí water system is located, including the dam and the water treatment station. This result indicates the dire need to conserve these areas' natural vegetation, where most of the fragility is associated with geological formations and soil classes. Despite presenting irregular occupation at the floodplains and springs areas (KNAPIK et al., 2011), the basin's green cover (shrubby, arboreal and tree stand) contributes to most of its area presenting low to intermediate fragility since they increase environmental stability. Aside from the natural vegetation protecting the soil from the 
rain and working as an obstacle to the runoff, it also plays a crucial role in water balance and regulating the main hydrological variables - evapotranspiration and water production - and the absence of vegetation can result in severe changes in the hydrological cycle and conservation of these environments (ALKAMA; CESCATTI, 2016; NOSETTO et al., 2012). Santos et al. (2007) recovered similar results while assessing the geo-environmental vulnerability in the State of Paraná, where they considered the Planalto do Alto Iguaçu's geomorphology as presenting low vulnerability to laminar and linear erosion.

On the other hand, the results indicate a high natural morphodynamic vulnerability (CREPANI et al., 1996) of the RS typologies due to the marked occurrence of "high to very high" fragility classes associated with current alluviation sediments and alluvial terraces. These materials present non-consolidated and heterogeneous character, formed through the sedimentary deposit of rivers (SALAMUNI et al., 2013). Therefore, these areas are extremely fragile and present low use potential. Most of the basin is composed of the Guabirotuba formation, which, despite generally occurring in smoother topographies with weakly undulated to undulated declivities (IBGE, 2007), is susceptible to erosive processes (ARAÚJO FILHO et al., 2017).

In the basin's central portion, the large area with "intermediate to high fragility" is associated with patches of Organosols over the recent sediments of current alluviations. The soils' vulnerability reflects the instability of the Organosols, Gleissols, and rocky outcrops. Organosols are organic soils with low use potential, high vulnerability, and great importance for preserving and conserving water sources and ecosystems (EBELING et al., 2011). Gleissols are located in lowlands, floodplains, and near water bodies, where the groundwater is closer to the surface (IBGE, 2007), working as environmental filters. Thus, these soil classes are considered crucial for conserving hydric resources, reinforcing the need for their conservation (IBGE, 2007; SCHEER et al., 2011). Similarly, rocky outcrops have high fragility since they present little to no soil cover, with many exposed rocks. These characteristics make these environments susceptible to processes like water erosion (XIONG et al., 2009). On the other hand, Red-yellow Latossol areas comprehend soils with "very low to low" fragility due to their structure and pedological development, added to the occurrence of smoother topographies (PETSCH et al., 2012).

In other areas, "intermediate to high" fragility is a consequence of the presence of Cambisols, Argisols, and rocky outcrops, associated with RS of "intermediate to high" fragility. According to our results, only $0.11 \%$ of the basin's area presents "high to very high" fragility. The predominant factor in these places was the greater declivity, with values between 20 and $30 \%$ and superior to $30 \%$. The greatest declivities were observed in the eastern of the Iraí river basin, where surfaces of slightly busy topography enable soil loss (IBGE, 2007) and indicate higher environmental fragility.

The natural shrub and tree cover in the eastern and western portions of the basin reduces the environmental fragility since they provide high soil protection and perform countless environmental roles. The wide range of ecosystem services provided by forests are crucial in maintaining the structural stability of slopes, acting in soil fixation, protecting water resources, and conserving the native flora and fauna. These characteristics decrease the region's environmental fragility (FU et al., 2013). In the basin's periphery, an increase in the occurrence of "low to intermediate" fragility classes are generally observed at the expense of decreasing the "very low to low" class. This increase in fragility results from the soil's high vulnerability caused, for instance, by temporary agriculture, water, and urban areas. Furthermore, we also observed an increase in the number of areas with "high to very high" fragility, which now occupy $0.39 \%$ of the area, primarily due to mining activities.

The EF and NVSL methods resulted in similar maps, with a congruent classification for $74 \%$ of the area, and assessed most of the Iraí river basin as presenting low to intermediate fragility. Nonetheless, the environmental fragility maps for both methods indicate that different results can be obtained on the threshold between fragility classes depending on the LU vulnerability. From the LU perspective, there was no regular response concerning the occupation types. In polygons with a less vulnerable green cover, such as tree and shrub cover and the forest stand, the NVSL method recovered higher fragility values. Alternatively, the EF method recovered higher fragility values when the LU vulnerability was higher, caused by mining, exposed soils, water, and temporary agriculture. While assessing the EF and NVSL of the Almada-Bahia river basin, Gomes (2013) found declivity as the most informative variable between both methods. Therefore, we can infer that the peculiarities of each area, especially its topography and LU, can drastically affect the environmental fragility values recovered by each method. The classification differences between the EF and NVSL methods result from the NVSL being calculated based on the attributes' arithmetic average, while the EF is weighted based on the LU. According to Spörl and Ross (2004), both methods with their respective technical-operational procedures take into consideration the same variables. Save some minor differences, the fragility calculation reflects the different ways of weighing the evaluated variables.

Our results indicate that the selection of the environmental fragility method depends on the relevance of the LU, favouring a more appropriate territorial management. The EF method (ROSS, 1994) resulted in higher fragility values for polygons where LU is more vulnerable, being considered a more conservative model. Therefore, in case the studied site presents extensive areas occupied by highly vulnerable LU classes, the EF 
method is the most appropriate to highlight this fragility. Specifically for the Iraí river basin, we believe giving greater importance to LU seems the best option since it represents a water source area, and LU categories can affect the water's quality (AQUINO et al., 2017).

The empirical assessment of the environmental fragility can subsidise the decision-making process regarding the use of watersheds. Studies of this kind allow us to propose action and environmental management plans to be implemented by the public and private sectors according to the local reality (ROVANI; VIERA, 2016). It is possible to assess which areas present the greatest fragility and understand why they are so unstable. Thus, we can identify where more attention is needed concerning occupation or decision-making on priority sites for the revegetation and recovery of degraded areas.

\section{CONCLUSIONS}

- The empirical assessment of the environmental fragility of the Iraí river basin enabled us to classify most of its area as presenting low to intermediate fragility. The polygons with shrub and tree cover and tree stand contributed to this result since they reduced the environmental vulnerability.

- The region's greatest vulnerabilities are associated with litho-geomorphological characters. These vulnerabilities were worsened by the LU classes, especially temporary agriculture, mining, and exposed soil.

- The NVSL method reduced the effect of the LU classes, decreasing the environmental fragility values, while the EF method recovered higher fragility values for the polygons where LU was more vulnerable. Nonetheless, both environmental fragility empirical assessment methods recovered congruent results, providing equal classifications for $74 \%$ of the Iraí river basin's area.

\section{ACKNOWLEDGMENTS}

We thank Conselho Nacional de Desenvolvimento Científico e Tecnológico (CNPq) for AKM's doctoral scholarship granted and FG's productivity grant.

\section{REFERENCES}

AGUASPARANA. Instituto das águas do Paraná. Mapeamento da bacia do Alto Iguaçu. Curitiba, 2015. Disponível em: <http://www.aguasparana.pr.gov.br/modules/conteudo/conteudo.php?conteudo=79> Acesso em: 03 Aug. 2015.

ALVARES, C. A.; STAPE, J. L.; SENTELHAS, P. C.; GONÇALVES, J. D. M.; SPAROVEK, G. Köppen's climate classification map for Brazil. Meteorologische Zeitschrift, Stuttgart, v. 22, n. 6, p. 711-728, Dec. 2013.

ALKAMA, R.; CESCATTI, A. Biophysical climate impacts of recent changes in global forest cover. Science, Washington, v. 351, n. 6273, p. 600-604, Feb. 2016.

AQUINO, A. R.; PALETTA, F. C.; ALMEIDA, J. R. Vulnerabilidade ambiental. São Paulo: Blucher, 2017.

ARAÚJO FILHO, R. N.; HOLANDA, F. S. R.; PEDROTTI, A.; OLIVEIRA SANTOS, T.; ROCHA, I. P. Influência dos atributos físicos-mecânicos do solo na estabilidade do talude do Baixo São Francisco. Scientia Agraria, Curitiba, v. 18, n. 4, p. 107-113, Oct./Dec. 2017.

CREPANI, E.; MEDEIROS, J.S.; AZEVEDO, L.G.; HERNANDEZ FILHO, P.; FLORENZANO, T.G.; DUARTE, V. Curso de sensoriamento remoto aplicado ao zoneamento ecológicoeconômico. São José dos Campos: INPE, 1996.

EBELING, A. G.; ANJOS, L. D.; PEREZ, D. V.; PEREIRA, M. G.; GOMES, F. D. F. Atributos químicos, carbono orgânico e substâncias húmicas em Organossolos Háplicos de várias regiões do Brasil. Revista Brasileira de Ciência do Solo, Viçosa, v. 35, n. 2, p. 325-336, Apr. 2011.

FARLIN, J.; GALLÉ, T.; PITTOIS, D.; BAYERLE, M.; SCHAUL, T. Groundwater quality monitoring network design and optimisation based on measured contaminant concentration and taking solute transit time into account. Journal of Hydrology, Holanda, v. 573, p. 516-523, Jun. 2019.

FU, B.; WANG, S.; SU, C.; FORSIUS, M. Linking ecosystem processes and ecosystem services. Current Opinion in Environmental Sustainability, Holanda, v. 5, n. 1, p. 4-10, Mar. 2013.

GOMES, R. L. Avaliação da fragilidade ambiental e vulnerabilidade natural à perda de solo da bacia hidrográfica do rio Almada-Bahia. Boletim de Geografia Maringá, Maringá, v. 31, n. 3, p. 41-53, Dec. 2013. 
GONÇALVES, G. G. G.; DANIEL, O.; COMUNELlO, E.; VITORINO, A. C. T.; ARAI, F. K. Determinação da fragilidade ambiental de bacias hidrográficas. Floresta, Curitiba, v. 41, n. 4, Oct./Dec. 2011.

INSTItUto BRAsileiro DE GEOGRAFIA E ESTATÍSTICA (IBGE). Manual Técnico de Pedologia. Rio de Janeiro: IBGE, 2007.

KNAPIK, H. G.; FERNANDES, C.; PICKBRENNER, K.; PORTO, M.; BASSANESI, K. Qualidade da água da bacia do rio Iguaçu: diferenças conceituais entre os modelos QUAL2E e QUAL2K. Revista Brasileira de Recursos Hídricos, Porto Alegre, v. 16, n. 2, p. 75-88, Apr./Jun. 2011.

MINERAIS DO PARANÁ (MINEROPAR). Potencialidades e Fragilidades das Rochas do Estado do Paraná. Curitiba: MINEROPAR, 2005.

NOSETTO, M. D.; JOBBÁGY, E. G.; BRIZUELA, A. B.; JACKSON, R. B. The hydrologic consequences of land cover change in central Argentina. Agriculture, Ecosystems \& Environment, Holanda, v. 154, p. 2-11, Jul. 2012.

PETSCH, C.; ZUCCHI, V. P.; BRAVO, J. V. M.; BUENO, M. B.; MINAKAWA, N. S. Elaboração das Cartas de Suscetibilidade e Potencialidade à Erosão Laminar em Douradina, Estado do Paraná. Revista Brasileira de Geografia Física, Recife, v. 2, p. 400-411, Mar. 2012.

RASHID, M.; LONE, M. A.; AHMED, S. Integrating geospatial and ground geophysical information as guidelines for groundwater potential zones in hard rock terrains of south India. Environmental monitoring and assessment, Holanda, v. 184, n. 8, p. 4829-4839, Sep. 2012.

ROSS, J. L. S. Análise empírica da fragilidade dos ambientes naturais e antropizados. Revista do Departamento de Geografia - USP, São Paulo, v. 8, p. 63-74, Jul. 1994.

ROVANI, F. F. M.; VIERA, M. Vulnerabilidade Natural do Solo de Silveira Martins-RS. Floresta e Ambiente, Seropédica, v. 23, n. 2, p. 151-160, 2016.

SALAMUNI, E.; NASCIMENTO, E. R.; SILVA, P. A. H.; OKA-FIORI, C. Geomorfologia do município de Curitiba-PR. Revista Brasileira de Geomorfologia, Curitiba, v. 14, n. 4, Oct./Dec. 2013.

SANTOS, L. J. C.; OKA-FIORI, C.; CANALlI, N.E.; FIORI, A.P.; SILVEIRA, C.T.; SILVA, J.M.F. Mapeamento da vulnerabilidade geoambiental do estado do Paraná. Brazilian Journal of Geology, São Paulo, v. 37, n. 4, p. 812-820, Dec. 2007.

SCHEER, M.B.; CURCIO, G.R.; RODERJAN, C.V. Funcionalidades ambientais de solos altomontanos na Serra da Igreja, Paraná. Revista Brasileira de Ciência do Solo, Viçosa, v. 35, p. 1113-1126, Aug. 2011.

SOUZA, A. F. A review of the structure and dynamics of araucaria mixed forests in southern Brazil and northern Argentina. New Zealand Journal of Botany, Nova Zelândia, v. 59, n. 1, p. 2-54, Sep. 2020.

SPÖRL, C.; ROSS, J. L. S. Análise comparativa da fragilidade ambiental com aplicação de três modelos. Geousp Espaço e Tempo, São Paulo, n. 15, p. 39-49, Jul. 2004.

XIONG, Y. J. et al. Rocky desertification and its causes in karst areas: a case study in Yongshun County, Hunan Province, China. Environmental Geology, Alemanha, v. 57, n. 7, p. 1481-1488, Jun. 2009. 